\title{
ХАРАКТЕРИСТИКА КОМПОНЕНТНОГО СОСТАВА ГРАММАТИЧЕСКОЙ КОМПЕТЕНЦИИ УЧАЩИХСЯ
}

\section{CHARACTERIZATION OF COMPONENT COMPOSITION OF STUDENTS' GRAMMATICAL COMPETENCE}

A. Ametov

T. Sapukh

Summary: In the article the component composition of students' grammatical competence is analyzed. In the beginning of this article authors give definitions of grammatical competence from the point of view of different researchers. As a research task was the authors' attempt to evaluate different approaches in determining the component composition of grammatical competence. And the conclusion is drawn about the actual component composition of students' grammatical competence.

Keywords: grammatical competence, grammatical competence of students, component composition of grammatical competence, theoretical and cognitive component, language component, speech component, intercultural competence.

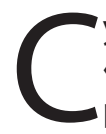

уществует ли общепринятая трактовка понятия «грамматическая компетенция» в современных реалиях иноязычного образования? Какой компонентный состав является оптимальным для формирования грамматической компетенции? Данная статья направлена на то, чтобы ответить на два этих вопроса, опираясь на описание основных, актуальных в современных реалиях обучения иностранным языкам, трактовок понятия «грамматическая компетенция» и современных исследований ее компонентного состава.

После принятия ФГОС в 2004 как одного из основополагающих документов в области образования, были проведены ряд исследований, направленных на изучение грамматической компетенции. Отечественные учёные $P$. П. Мильруд, И.Р. Максимова, И.Л. Бим, Л. К. Бободжанова, С.В. Мерзляков, О.М. Рябцева, А.С. Шимичёв, Н.А. Кафтаилова, Е.Н. Белова и др. внесли свой вклад в исследование этой проблемы, трактовки термина и, соответственно, определения компонентного состава грамматической компетенции. Термин «грамматическая компетенция» был принят многими учёными в качестве одной из требуемых компетенций при формировании коммуникативной компетенции. В доказательство этого можно привести высказывания А.С. Шимичёва: «Традиционно грамматическую компетенцию, наряду с фонетической и лексической, включают в состав языковой (лингвисти-

\author{
Аметов Азиз Куанышевич \\ Оренбургский государственный университет \\ azizametov@mail.ru \\ Сапух Татьяна Викторовна \\ К.п.н., доцент, Оренбургский государственный \\ университет \\ tatsap@mail.ru
}

Аннотация: В статье приведён анализ компонентного состава грамматической компетенции учащихся в современных реалиях иноязычного обучения. В начале статьи даются определения грамматической компетенции с точки зрения разных исследователей. В качестве исследовательской задачи авторами была определена попытка оценить современные подходы в определении компонентного состава грамматической компетенции для успешного формирования грамматической компетенции учащихся. В конце статьи делается вывод 06 актуальном компонентном составе грамматической компетенции в современных условиях обучения иностранным языкам.

Ключевые слова: грамматическая компетенция, грамматическая компетенция учащихся, компонентный состав грамматической компетенции, теоретико-когнитивный компонент, языковой компонент, речевой компонент, межкультурная компетенция.

ческой) компетенции, которая, в свою очередь, является неотъемлемой частью коммуникативной компетенции» [1, с.132] и О.Н. Подгорской, которая отмечает: «Грамматическая компетенция - это составная часть языковой компетенции, входящей, в свою очередь, в структуру иноязычной коммуникативной компетенции» [2, с.132].

Исследовав работы вышеуказанных учёных, мы можем сказать, что грамматическая компетенция является одним из компонентов языковой компетенции, которая, по мнению А.С. Шимичёва, «предполагает владение словарным составом языка в сочетании с умением объединять лексические единицы в высказывания посредством использования грамматических правил оформления речи»[1, с.132].

Рассмотрим общеизвестное определение, принятое Советом Европы: «Грамматическая компетенция - это знание грамматических элементов языка и умение их использовать в речи. <...> Грамматическая компетенция включает способность понимать и выражать определённый смысл, оформляя его в виде фраз и предложений, построенных по правилам данного языка (в отличие от механического воспроизведения заученных образцов)» [3, с. 107-108]. В этом определении ясно сказано, что грамматическая компетенция - это не заученные знания, а способность оперировать грамматическими правилами для оформления высказывания. На начальном этапе 
внедрения компетентностного подхода эта трактовка была общепризнанной, но впоследствии оказалось, что грамматическая компетенция не была в полной мере исследована, в частности не был чётко определён ее компонентный состав. В результате учёные начали предлагать свои наработки в определении этого понятия. Изучив литературу по данной теме, мы выяснили, что на современном этапе существует три современных подхода (когнитивный, коммуникативно-когнитивный и межкультурный) для формирования грамматической компетенции.

Отечественный учёный, автор когнитивного подхода в изучении грамматической компетенции, Р.П. Мильруд утверждает, то что прежде всего грамматическая компетенция связана с грамматической компетенцией учащихся. Грамматическая компетенция учащихся - это семантическая сеть (Sternberg R.2009), в которой взаимосвязанные узлы выполняют функцию слотов для заполнения информацией. «Применительно к грамматической компетенции учащихся, ментальные пространства (в терминологии всемирной паутины Web 3.0 их именуют «онтологиями») представляют собой содержательные области усвоенных практических и теоретических знаний грамматики. Это еще раз подтверждает положение о том, что грамматическая компетенция учащихся проявляется на двух уровнях: осуществления и контроля грамматической стороны речевой деятельности»[4, с.137-138].

Р.П. Мильруд представляет грамматическую компетенцию в виде модели и приводит следующее определение: «Когнитивная модель грамматической компетенции учащихся» - это абстрактное отображение вербальными и графическими средствами психолингвистического механизма организованной и обратимой трансформации «мысль - предложение» в коммуникативно-познавательной деятельности»[4, с.134].

В построении структуры грамматической модели компетенции учащихся Р.П. Мильруд использовал терминологию когнитивной психологии и лингвистики и внёс в эту модель следующие компоненты:

1. грамматические концепты

2. грамматические экземпляры

3. грамматические категории

4. грамматические прототипы

5. грамматические фреймы

6. грамматические сценарии

7. грамматические схемы

8. грамматическое творчество.

Далее Р.П. Мильруд описывает процесс работы этой структуры следующим образом:

«.....грамматические концепты обобщают идентич- ные «экземпляры» и позволяют отнести их к тому или иному грамматическому явлению с помощью соответствующего термина. Грамматические категории дают возможность объяснить грамматические структуры с помощью выведенных правил. Грамматические прототипы нужны для того, чтобы выделить типичные экземпляры английского предложения, осознавая существование смешанных по форме и функции структур (пограничных случаев и исключений из правил). Грамматические фреймы позволяют более четко очертить границы правильных грамматических явлений и ошибочных употреблений языка. Грамматические сценарии нужны для построения предложений различных типов. Грамматические схемы интегрируют элементы знаний в единую систему языкового строя. Грамматическое творчество есть реальная форма речевого поведения учащихся»[4, c.144].

Проанализировав вышеуказанное исследование грамматической компетенции, мы пришли к выводу: в основу этой модели положены принципы работы компьютера, компьютерных программ и других вычислительных устройств, в которых есть основная память и оперативная память. В основную память загружаются данные, которые хранятся в ней, а в случае необходимости оперативная память будет пользоваться этим данными для выполнения определённых задач. Данный учёный делает акцент на то, что сам учащийся и его творческие способности при составлении высказывания являются основополагающими.

Коммуникативно-когнитивного подхода придерживаются Ю.А. Ситнова и Е. А. Рублева. Е.А. Рублёва определяет грамматическую компетенцию как «формирование специальных грамматических когнитивных моделей, которые хранятся в мозге отдельно от моделей смысловых и вызываются при речепорождении согласно грамматическим обязательствам смысловых моделей. Однако грамматические обязательства не предполагают автоматический вызов определенной грамматической модели, они несут в себе лишь первичное означивание, вторичное означивание осуществляется коммуникантом в соответствии с его прагматической интенцией (мотивом)»[5, с.12].

В своих исследованиях Е.А. Рублёва согласна с представителями когнитивного подхода, в концепции хранения данных, а также принципов работы при составлении высказывания, но в плане реализации автор этого определения утверждает, что назначение составленного высказывания могут отличаться от первичного означивания, то есть автор отмечает важность не только когнитивного подхода, но и важность коммуникативного подхода в развитии грамматической компетенции.

Ю.А. Ситнов выделяет следующие компоненты грам- 
матической компетенции:

1. знание грамматических единиц как носителей обобщённых грамматических свойств, а также средств выражения грамматических значений,

2. умение адекватно использовать их в речевой деятельности в различных ситуациях общения.)» [6, c.7-8].

Упрощённая модель Ю.А. Ситнова выглядит следующим образом: теоретические знания и способности в грамматике реализуются с помощью умения использовать эти знания и способности в разных контекстах. Полагаем, что данное определение грамматической компетенции является близким к истине, а модель понятной для читателей и методистов. Действительно, информация хранится в мозге в виде моделей грамматических явлений, но в реальных ситуациях общения каждое грамматическое явление может быть реализовано поразному, исходя из того, что все речевые ситуации могут отличаться друг от друга.

Следующий подход - межкультурный, который сейчас активно разрабатывается А.С. Шимичёвым и др. учёными. В своих исследованиях А.С. Шимичёв дал следующее определение грамматической компетентности:«.... владение определенным набором грамматических знаний, навыков и умений, способность в ходе межкультурного взаимодействия извлекать и адекватно интерпретировать явления иноязычной культуры, выраженные грамматическими средствами, выполнять иноязычную речевую деятельность согласно нормам изучаемого языка» [7, с.12]. А также добавляет к определению, что все компоненты грамматической компетенции подчинены межкультурной компетенции, при выборе моделей высказывания межкультурная компетенция играет ведущую роль. Он определяет межкультурную компетенцию как «... способность воспринимать, осознавать и интерпретировать родную и иноязычную картины мира, учитывать межкультурные различия в процессе иноязычной коммуникации с представителями иного лингвокультурного сообщества» [7, с.11].

Модель грамматической компетенции он выстраивает следующим образом:

1. Теоретико-когнитивный компонент.

2. Языковой компонент.

3. Речевой компонент. (Там же)

Все эти компоненты подчинены межкультурной компетенции, которая позволяет формировать грамматическую компетенцию.

Изучив работы А.С. Шимичева, делаем следующие выводы:

1. Теоретико-когнитивный компонент - это познания учащихся в теоретической части грамматики, в этом компоненте ведущую роль играет межкультурная компетенция. Каждое правило учащийся соотносит с родным языком, и достигает понимания с помощью картины мира своего языка.

2. Языковой компонент - это способность производить различные операции с составляющими теоретико-когнитивного компонента. Также и в этом компоненте межкультурная компетенция играет ведущую роль, так как все эти операции будут производиться с учётом разницы между картиной своего языка и иностранного языка.

3. Речевой компонент, как мы об этом уже говорили, в других подходах - это умение реализовать содержание двух предыдущих компонентов в речевых ситуациях. В этом компоненте также главную роль играет межкультурный компонент, так как речевая ситуация и предполагает межкультурное общение с носителем языка, и межкультурная компетенция является основополагающей для выбора моделей всех трёх компонентов. В защиту перспективности этого подхода нужно сказать, что за последнее время изучением влияния культурного компонента занимаются всё больше и больше учёных (Л.К. Бободжанова, Н.А. Кафтайлова, М.В. Лебедева, О.Н. Подгорская, С.Г. ТерМинасова и др.).

Все вышеуказанные учёные, в общем, сходятся во мнении, что формирование межкультурной компетенции невозможно без формирования грамматической компетенции. Определением Н.А. Кафтайловой можно подытожить общее описание межкультурного подхода: «Грамматическая компетенция - это способность индивида понимать и формулировать в ходе межкультурной коммуникации смысл высказывания на основе осуществления когнитивной деятельности по выявлению специфики грамматических форм выражения национально-культурных концептов, присущих иной и родной картинам мира». [8, с.112-113].

Эти три основные подхода, чаще всего упоминаются в научных изданиях, а также имеют существенное число сторонников на современном этапе развития обучения иностранным языкам.

В связи с изменениями в образовании в целом и в связи с тем, что за последнее время широкое распространение стало получать дистанционное обучение нужно обратить внимание на исследования отечественных учёных С.В. Мерзляков и Е.Н. Белова - сторонников автономного обучения для формирования грамматической компетенции. Приведём Определение С.В. Мерзлякова: «...готовность и способность человека к коммуникативно-целесообразному и ситуативно-адекватному использованию иноязычных грамматических знаний, навыков и умений в целях реализации своего речевого 
поведения на данном иностранном языке в процессе общения» [9, с.97]. В этом определении учёный утверждает, что способность и готовность к применению грамматических правил языка необходимо при формировании грамматической компетенции. Описывая его концепцию автономного обучения, можно сделать следующие выводы:

- Для формирования грамматической компетенции нужно формировать готовность применять грамматические правила для составления высказывании;

- Формирование грамматической компетенции будет более успешным вместе с формированием автономной деятельности учащегося.

Автономная деятельность учащегося, по определению Мерзлякова, - «это обучение по индивидуальному плану, дополняющему, расширяющему и углубляющему знания, получаемые школьником во время классной и внеклассной активности» [9, с.97].

Мерзляков подчёркивает, что грамматическая компетенция - это не что-то застоявшееся и неизменное, она требует постоянной работы над ее развитием. И в этом процессе автономная деятельность учащегося является одним из важных факторов формирования грамматической компетенции.
Подводя итоги всего вышесказанного, нужно отметить, что в каждой из современных трактовок понятия «грамматическая компетенция» определяют как способность составлять высказывания, используя грамматические правила или грамматические модели, хранящиеся в памяти. Основные дискуссии ведутся именно по компонентному составу грамматической компетенции. Изучив три основных подхода к развитию грамматической компетенции, нужно отметить, что межкультурный подход является одним из самых оптимальных на данном этапе. Действительно, для того, чтобы составить высказывание нужно иметь багаж знаний в грамматике, нужно уметь оперировать с этим багажом знаний, нужно уметь выбирать грамматические модели для составления высказывания с учётом специфики каждой речевой ситуации. При этом межкультурная компетенция управляет всеми этими компонентами, так как при формировании каждого компонента картина мира родного языка соприкасается с картиной мира иностранного языка. Но вместе с этим к компонентному составу, по нашему мнению, необходимо добавить ещё и такой компонент как автономная деятельность учащегося, так как сформированное умение учиться и работать самостоятельно является необходимым в современных реалиях обучения иностранным языкам.

\section{ЛИТЕРАТУРА}

1. Шимичев А.С. «0 межкультурной профессионально ориентированной грамматической компетенции учителя иностранного языка»//Педагогическое Образование в России изд. Уральский государственный педагогический университет,2014 г. № 9. -С. 131-136.

2. Подгорская 0.Н. «Формирование грамматической компетенции как составляющей иноязычной коммуникативной компетенции будущего учителя иностранного языка» // Известия Волгоградского Государственного педагогического университета, 2018 г. № 8. -С. 19-24.

3. бщеевропейские компетенции владения иностранным языком: изучение, обучение, оценка // Департамент по языковой политике, Страсбург. М.: МГЛУ, 2005. 247 с.

4. Мильруд Р.П. Максимова И.Р. «Когнитивная модель грамматической компетенции учащихся» // Язык и Культура изд. Национальный исследовательский Томский государственный университет, 2014. № 2. -С. 134-145.

5. Рублева Е.А. Совершенствование иноязычной грамматической компетенции с использованием тестовой композиции (на материале испанского языка): автореф. дис. ... канд. пед. наук. Пятигорск, 2006.

6. Ситнов, Ю.А. Коммуникативно-когнитивный подход к развитию грамматической компетенции студентов лингвистов (на материале сложных грамматических явлений испанского языка) : автореф. ... д д-ра пед. Наук / Ю.А. Ситнов. - Пятигорск, 2005. - 35с.

7. Шимичев А.С. Формирование грамматической компетенции студентов бакалавриата по направлению подготовки «Лингвистика» (Межкультурный подход): автореф. дис. ... канд. пед. наук. Нижний Новгород, 2018г.

8. Кафтайлова Н.А. Сущностная характеристика грамматической компетенции как компонента межкультурной компетенции// Альманах современной науки и образования изд. «Грамота»,2011. № 1. -С. 109-113.

9. Мерзляков С.В. Место и роль формирования грамматической компетенции при автономном обучении иностранному языку // Современные проблемы науки и образования изд. Издательский дом «Академия Естествознания», 2014г.№ 4. - С. 97. 